\title{
EVALUATION OF WATTLE REACTION AND ANTIBODY RESPONSE IN DIFFERENT CHICKEN BREEDS
}

\author{
V. BENDA, A. HAMPL and Kateřina TRTKOVÁ \\ Institute of Animal Physiology and Genetics, Czechoslovak Academy of Sciences, 10400 Prague
}

Received November 14, 1989

\begin{abstract}
Benda V., A. Hampl, Kateřina Trtková: Evaluation of Wiattle Reaction and Antibody Response in Different Chicken Breeds. Acta vet. Brno, 59, 1990: 151-156.

The intensity and kinetics of antibody production as well as wattle reaction to the natural antigens with different thymus dependence in adult birds of two layer breeds - White Leghors (WL) and Rhode Island Red (RIR) - were investigated. The breeds differed significantly in both humoral and cellular immune reactivity to sheep red blood cells (SRBC) and Brucella abortus crude antigen (BA). This patterns are inherited showing a strong paternal influence on antibody formation. Data obtained in this trial indicate the importance of selection on appropriate immune response in poultry breeding programs.
\end{abstract}

Wattle reaction, natural antibodies, breed differences, immunoreactivity

The origin of the history of thousands years of breeding of the domestic fowl may be traced in Asia, from where this species, important from the economy standpoint, has been propagated throughout the world. It may serve by way of an example of an exceptionally successful selection with respect to remarkable useful characteristics such as the growth and reproduction, since from the ancient times, the top annual production of eggs was increased by a factor exceeding $5-i$. e. from 60 to more than 300 eggs. To a similarly remarkable extent, the breeders stimulated the growth and production of the muscle mass, which is formed in specialized lines, at a feed conversion in a ratio of $2: 1$, with a much higher rate as compared to primitive breeds. The high production, approaching the physiologic limits of the organism brings, however, also certain negative consequences, the most important of them beeing undoubtedly a reduced adaptability and resistance to adverse environmental effects. By this concept we mean, besides low-quality feed, stabling and treatment and particularly pathogenic effects of a wide scale of macro- and microparasites, whose interaction with the host modifies to different degrees the health condition and thus, it threatens the population fitness (Templeton et al. 1988). Thus, the increasing production also results in increasing costs for the prevention and treatment of diseases of the parasitic, bacterial or viral origin. These losses can be faced successfully on the basis of breeding, since it is known that immunology mechanism, forming a base of the natural resistance of animals are determined genetically (Crittenden 1983). Revealing of disturbances of the immunity or possibly of quantitative differences in the immune response in different breeds of the fowl is facilitated thanks to a number of methods ( $\mathrm{V}$ an der $\mathrm{Zijpp} \mathrm{1983),} \mathrm{which} \mathrm{were} \mathrm{used} \mathrm{in} \mathrm{our} \mathrm{experiments} \mathrm{for} \mathrm{comparing}$ selected parameters of the cellular and humoral immunity in two commercial layer breeds.

\section{Materials and Methods}

\section{Chickens}

Two commercial layer breeds were studied - White Leghorn (WL) and Rhode Island Red (RIR). Male chickens were kept in cages and immunized at the age of 17 weeks.

Antigens

Sheep red blood cells (SRBC) and crude antigen prepared from germs of the Brucella abortus (BA) - strain S99 Weybridge (Bioveta Ivanovice, Czechoslovakia) were used for the immunisation in the form of a $10 \%$ suspension in physiologic saline. Phytohemagglutinin P (SIGMA, St. Louis, USA) was dissolved in a concentration of $1 \mathrm{mg} / \mathrm{ml}$, also in physiologic saline. 
Table 1

Experimental design

\begin{tabular}{|c|cr|c|c|c|}
\hline Group & Breed & $\mathrm{n}$ & Sensitization & Antibody & Immunization \\
\hline & & & & & \\
1 & WL & 8 & - & SRBC & SRBC \\
2 & RIR & 10 & - & SRBC & SRBC \\
3 & WL & 8 & - & BA & BA \\
4 & RIR & 10 & BA \\
5 & WL & 8 & SRBC & SRBC & SRBC \\
6 & RIR & 10 & SRBC & SRBC & SRBC \\
7 & WL & 8 & BA & BA & BA \\
8 & RIR & 10 & BA & BA & BA \\
9 & WL & 8 & - & - & PHA \\
10 & RIR & 10 & - & - & PHA \\
\hline
\end{tabular}

Immunisation

The experimental design is shown in Table 1 . The chickens were first sensitized by administering antigenic suspensions in an amount of $1 \mathrm{ml}$ intramuscularly (groups 5 to 8 ) or they received physiologic saline by the same method (groups 1 to 4 ). Blood samples for determining antibodies by the agglutination in microtitration plates (SRBC) or test tubes (BA) based on formely published procedures (Petrovský et al. 1987), were taken on the 7th day after the immunisation. The highest dilution of the serum with a significant agglutination activity was considered as the highest titre of the sample and expressed as $\log _{2}$. Just after sampling, the chickens were immunized by administering $0.1 \mathrm{ml}$ of the suspension SRBC, BA or PHA into the right wattle. The left wattle was injected with the same volume of the physiologic saline and it served as a negative control. The change in the thickness was expressed by subtracting the initial thickness from that measured 24 and 48 hours after the application into the wattle.

Statistical analysis

The mean responses were evaluated by the analysis of variance and by Student's t-test.

\section{Results}

Only significant increases of wattle thickness after 24 and $48 \mathrm{hr}$ were statistically evaluated. At this time no significant reactions were seen in the saline treated control wattles. Values presented in Fig. 1-4 are expressed as mean $\pm S E M$, bars without common letter are significantly different at the 0.05 level.

Our data indicate that

- both breeds show significant differences to SRBC, BA and PHA at $24 \mathrm{hr}$ without any sensitization (Fig. 1-3)

- at this time the breed differences may be negatively influenced by previous sensitization (Fig. 1, 2)

- only the SRBC response remains still at $48 \mathrm{hr}$ breed dependent (Fig. 1)

- no measurable PHA response was seen in birds at $48 \mathrm{hr}$ (Fig. 3)

- natural antibodies to SRBC are significantly higher in untreated RIR birds (Fig. 4) 


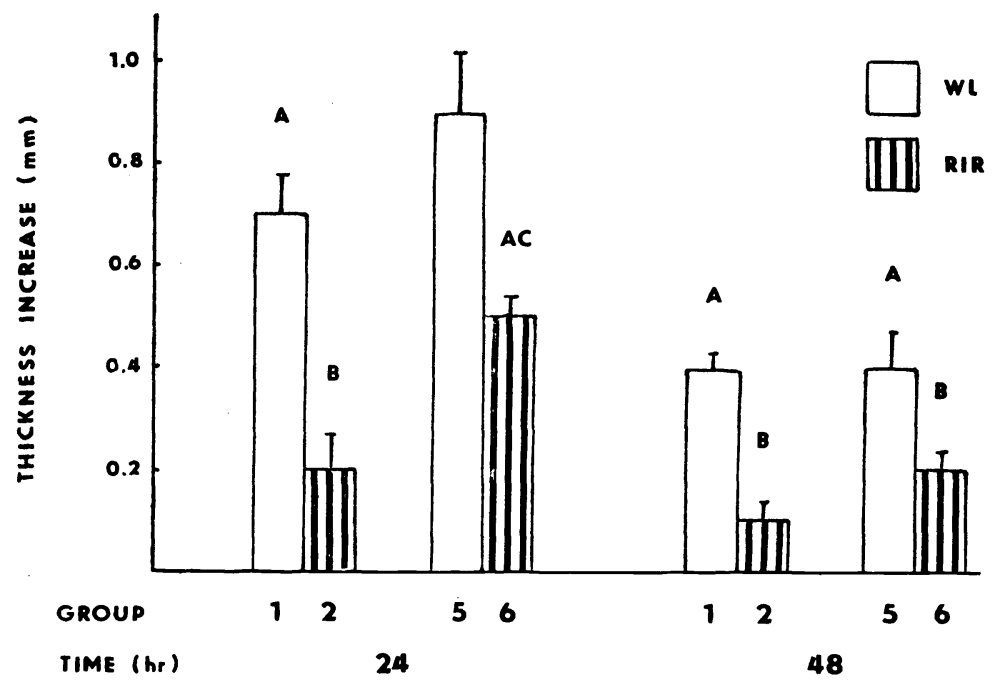

Fig. 1. Wattle response to SRBC

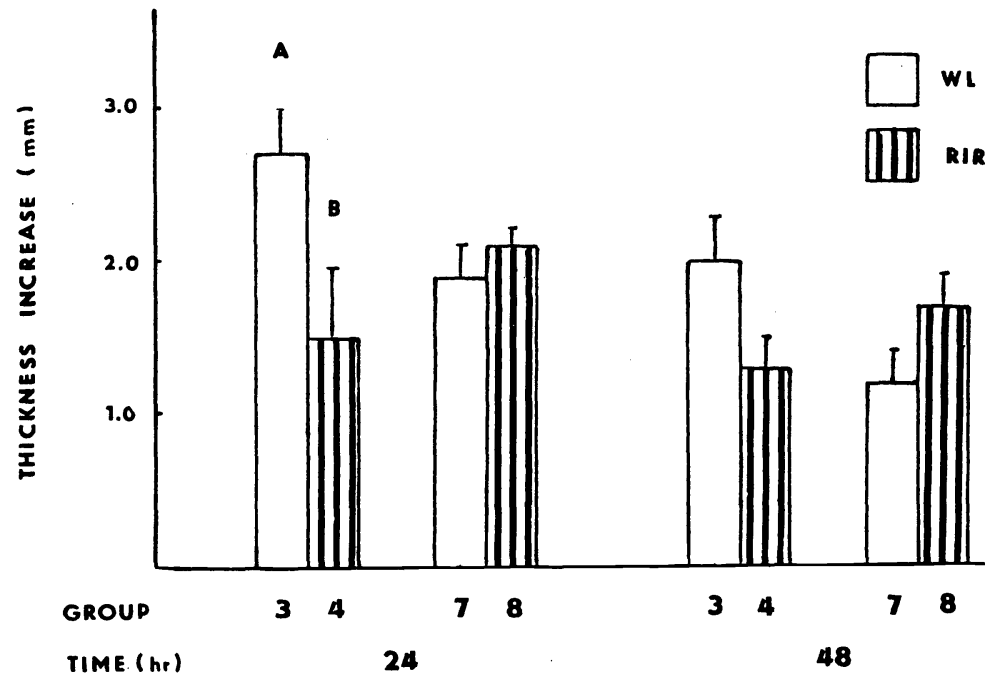

Fig. 2. Wattle response to BA

\section{Discussion}

As can be seen from the results, differences between particular breeds in our experiments were manifested already by different levels of natural antibodies against the SRBC, a T-dependent antigen, which was higher remarkably in RIR. However, by contrast to WL, these birds exerted an only slight reaction after the administration of the SRBC. No differences were observed during the immunisation with BA, a B-dependent antigen, in spite of the fact that in both lines these was a reaction manifested by a remarkable increase of the titre by several 


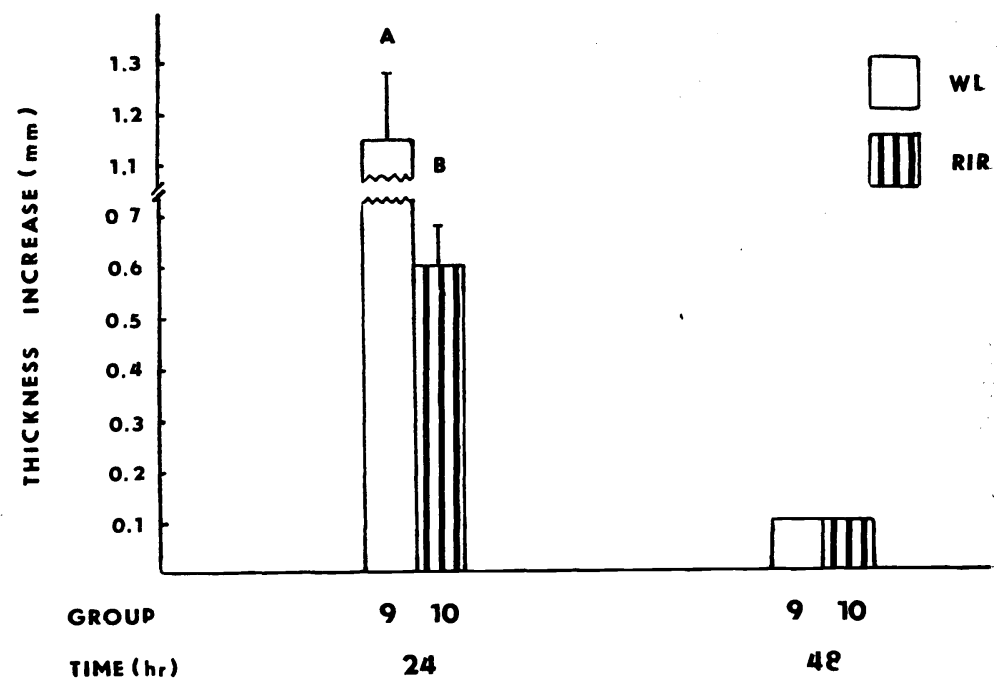

Fig. 3. Wattle response to PHA

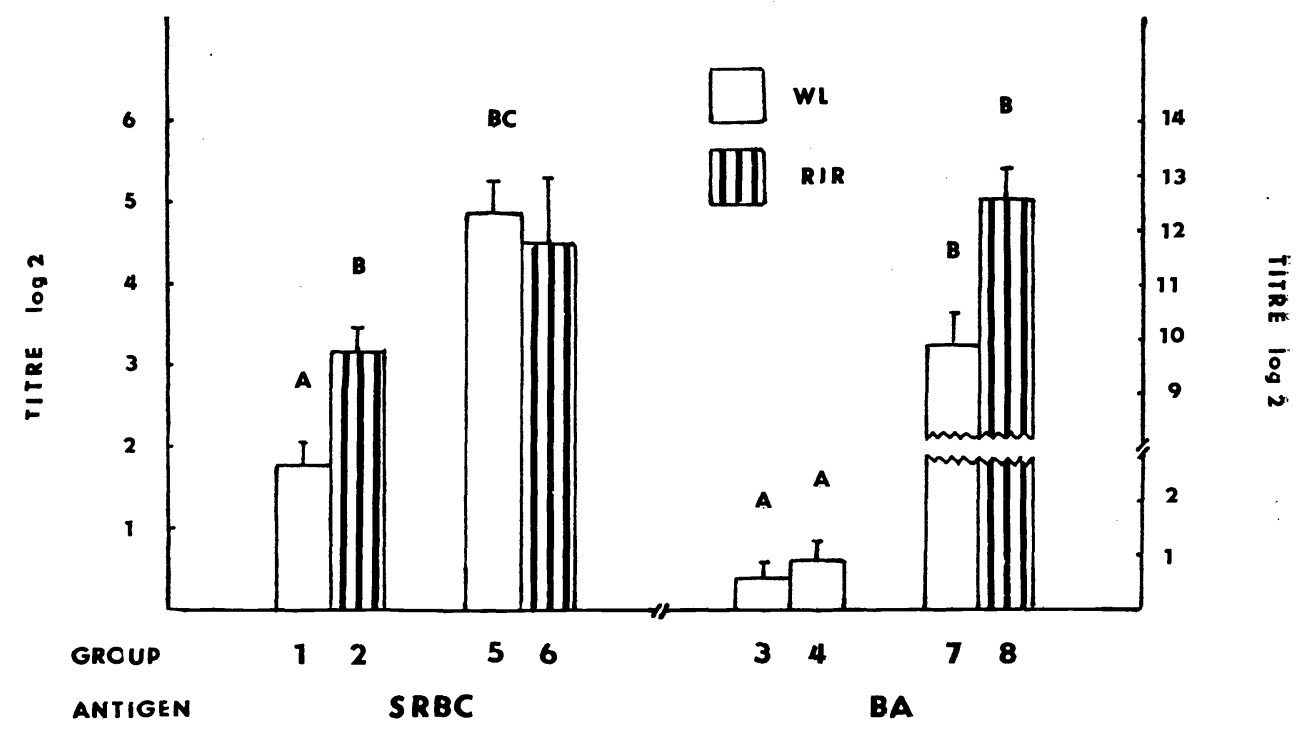

Fig. 4. Antibody response to SRBC and BA

dilutions. Similar results were observed formerly (Petrovský et al. 1987) and, in addition to this, during a transfer of this trait to the descendants, we were able to show a remarkable effect of sex. However, the focus of interest of the present work was in evaluating the difference of the wattle reaction, i.e. manifestation of the cellular immunity in vivo (Krejčí et al. 1974; Edelman et al. 1986). Based on our findings, besides the characteristic kinetics of the reaction after one and two days, there is also an effect of the preceding sensitization with 
a natural antigen, which exerted a rather negative effect by contrast to results of other authors (Cotter and Wing 1987), on the intensity of the oedema and on the differences between the breeds. The two breeds were also significantly different after the mitogenic stimulation with the PHA, in spite of the fact that the reaction was measurable only after 24 hours. In this case, there was a decisive effect of the sex of our animals, since Taylor et al. (1987) also noticed that cocks react more readily to PHA than hens the reaction resolution being, however, more rapid.

It can be concluded that significant differences were found between the two breeds in the humoral as well as cellular immunologic responses. After evaluating of the two components of the immunity, SRBC were shown to be a universal test antigen. A further attention should be paid to a problem whether an increased immunoreactivity of the WL breed, reflected adversely e.g. in an increased susceptibility to the Marek's disease (Longenecker et al. 1975), may be associated with a totally higher rate of mortality observed in this layer breed under our conditions.

\section{Sledování lalůčkové reakce a protilátkové odpovědi u různých plemen kura}

U dvou nosných plemen kura - WL a RIR - byla sledována vedle intenzity a kinetiky tvorby protilátek též lalưčková reakce na aplikaci prírozených antigenů lišících se $\mathrm{v}$ závislosti na thymu. Plemena se průkazně liší jak v humorální, tak $i$ buněčné imunoreaktivitě $k$ ovčím erytrocytům (SRBC) i nepurifikovanému antigenu Brucella abortus (BA). Tyto vlastnosti se dědí, přičemž se u tvorby protilátek projevuje silný patroklinní vliv. Výsledky získané v pokusu upozorňuji na význam selekce na optimální imunitní odpověd v rámci šlechtění drůbeže.

\section{Исследование реакции доли и ответа на антитела у разных пород күриц}

У двух пород несүшек - WL и RIR - проводили исследования наряду с интенсивностью и кинетикой образования антител также реакции доли на дачу естественных антигенов, отличающихся в зависимости от зобной железы. Породы явно отличались не только в гүморальной, но и клеточной иммунореактивности на эритрциты овец (SRBC) и неочищенному антигену Brucella abortus (BA). Данные свойства наследүются, при этом при образовании антител наблюдается интенсивное патроклинное влияние. Полученные в ходе эксперимента результаты свидетельствуют о значении селекции в оптимальном иммунном ответе в ходе селекции птицы.

\section{References}

COTTER, P. F. - WING, T.: Kinetics of the wattle reaction to human plasma. Avian Diseases, 31, 1987: 643-648.

CRITTENDEN, L. B.: Recent advance in the genetics of disease resistance. Avian Pathology, 12, 1983: 1-8.

EDELMAN, A. S.-SANCHEZ, P. L.-ROBINSON, M. E.-HOCHWALD, G. M.THORBECKE, G. J.: Primary and secondary wattle swelling response to phytohemagglutinin as a mesure of immunocompetence in chickens. Avian Diseases, 30, 1986: 105-11. 
KREJČ́, P. - KARAKOZ, I.-PEKÁREK, J.-HRABA, T.-HÁLA, K: Differences between inbred Lines of chickens in development of tuberculin hypersensitivity. Immunology, 27, 1974: $133-136$.

LONGENECKER, B. M.-PAZDERKA, F.-RUTH, R. F.: Modification by herpesvirus of hereditary GvHR competency. Journal of Immunogenetics, 2, 1975: 54-64.

PETROVSKÝ, E.-KALOVÁ, J.-BENDA, V.: Antibody response in domestic fowl as affected by different immunization methods. Acta vet. Brno, 56, 1987: 449-453.

TAYLOR, R. L. Jr. - COTTER, P. F. - WING, T. L.-BRILES, W. E.: Major histocompatibility (B) complex and sex effects on the phytohemagglutinin wattle response. Animal Genetics, 18, 1987: 343-350.

TEMPLETON, J. W.-SMITH III, R.-ADAMS, L. G.: Natural disease resistance in domestic animals. J. of the Amer. Vet. Med. Assoc., 192, 1988: 1306-1314.

VAN DER ZIJPP, A. J.: Breeding for immune responsiveness and disease resistance. W. P. S. A. Journal, 39, 1983: 118-131. 